Lucas Lemos da Silva

Federal University of Rio Grande do Su Department of Materials Engineering

Brazil

Leila Cristina Nunes Ribeiro

Federal University of Rio Grande do Sul Department of Materials Engineering

Brazil

Galileo Santacruz

Federal University of Rio Grande do Sul Department of Materials Engineering

Brazil

Sabrina Arcaro

Federal University of Rio Grande do Sul Department of Materials Engineering

Brazil

Annelise Koop Alves

Federal University of Rio Grande do Sul Department of Materials Engineering

Brazil

Carlos Pérez Bergmann

Federal University of Rio Grande do Sul Department of Materials Engineering

\section{Glass Foams Produced from Glass and Yerba Mate (Ilex paraguarinensis) Waste}

In this study, compositions containing green glass bottles and desiccated and crushed yerba mate (Ilex paraguarinensis) of different mass fractions (10-30\%) were prepared to obtain glass foams for thermal insulation purposes. These compositions were uniaxially pressed (at $40 \mathrm{MPa}$ ), and the compact powders were fired at $850^{\circ} \mathrm{C}$ and $900^{\circ} \mathrm{C}$ for $60 \mathrm{~min}$ in order to investigate the effect of yerba mate and temperature on the formation of pores and the thermal and mechanical properties of the processed glass foams. The results indicated that the glass foams displayed porosities ranging from 65.3-88.3\%, compressive strengths ranging from 15-1.5 $\mathrm{MPa}$, and thermal conductivities ranging from $0.6-0.04 \mathrm{~W} \cdot \mathrm{m}^{-1} \cdot \mathrm{K}^{-1}$. Cumulatively, these glass foams are candidate thermal insulators that have advantageous properties for various industrial applications.

Keywords: glass foams, wastes, yerba mate.

\section{INTRODUCTION}

A growing interest in porous ceramics has been mainly associated with their specific properties, such as high surface area, high permeability, and low density and thermal conductivity. These properties are all related to the characteristics of ceramic materials, such as high refractoriness and resistance to chemical attacks [1]. Several different materials can be used for the manufacture of porous ceramics, such as alumina, mullite, silicon carbide, zirconia, and hydroxyapatite. However, recent studies have shown numerous advantages and possible uses for discarded glass in the synthesis of glass foams [2-13].

Lately, the progressive demand for more sustainable materials in industry, powered by the usage of renewable and/or natural resources, have gained importance from structural plastic composites [14-19] to mobility solutions [20-23], aiming to provide, if not full recyclability, at least an eco-friendlier supply chain on diversified material applications. On that matter, the glass used in the manufacturing of glass foams can be glass that has been disposed of as waste. The recycling and use of glass waste can generate large energy savings because the production of $1 \mathrm{~kg}$ of new glass requires $4500 \mathrm{~kJ}$ of energy, while the production of $1 \mathrm{~kg}$ of recycled glass requires only $500 \mathrm{~kJ}$ [24]. In order to reduce production costs and obtain raw materials, several modifications have been applied to the

Received: March 2017, Accepted: September 2017

Correspondence to: Prof. Carlos Perez Bergmann

Federal University of Rio Grande do Sul, Department of

Materials Engineering, Porto Alegre, Brasil

E-mail: bergmann@ufrgs.br

doi:10.5937/fmet1801070L processing techniques and starting materials [4]. Furthermore, environmental and social concerns have increased the need for novel methods of converting waste into useful products while minimizing energy consumption and the use of raw materials in order to reduce environmental impacts $[25,26]$.

Commercial glass foams are used for various applications, such as the construction of roofs, walls, floors, ceilings, fireplaces, and grills used at working temperatures below $500^{\circ} \mathrm{C}$ [11]. These glass foams display porosity values ranging from $85-95 \%$, which can be opened, closed, or mixed. They have compressive strength values ranging from $0.4-6 \mathrm{MPa}$ and thermal conductivity values of $0.04-0.08 \mathrm{~W} \cdot \mathrm{m}^{-1} \cdot \mathrm{K}^{-1}$. Furthermore, glass foams are chemically stable, nontoxic, and non-flammable. Polymeric foams are typically employed in industrial applications [4,11,27].

Several techniques for producing porous ceramics are currently used, and the processing steps generally consist of preparing a suspension of ceramic powder, which is then formed and heat-treated (fired). The best known forming methods include the replication method, gelcasting, the template or sacrificial method, and foaming and incorporation of porogenic agents (pore formers) $[11,28]$. Because of its simplicity, one of the techniques widely used for the production of glass foams is the addition of a foaming agent to the powdered glass, followed by its removal from the heat treatment step to form a cellular structure [4,27]. The foaming agents can be synthetic (polymers) or natural (mineral or vegetable residues) [2,27].

The natural residues are composed of different elements, such as cellulose, hemicellulose, and lignin, which open many value-adding opportunities and can be a low-cost alternative for use as foaming agents [29]. 
There is a worldwide trend towards the recycling of waste with calorific value in the ceramic industry. Some research studies have focused on various technologies, such as the use of pulp and paper industry waste, urban waste treatment plants, and agro-industrial residues (including banana leaves, rice husks, and sugar cane bagasse). This is because of the large volume of these wastes and the large environmental impacts they have on water resources and, therefore, society as a whole. These residues can be used to obtain glassy foam. In addition, glass foams represent an interesting use for glass and vegetable wastes from an economic and environmental point of view.

Significant plant waste in temperate and subtropical regions of Brazil, Paraguay, and Argentina comes from Yerba mate (Ilex paraguariensis) cultivation [2, 30-33]. Worldwide, the production of yerba mate is significant. Brazil produces 860 thousand tons of green mate [34], Argentina produces 690 thousand tons of green herbs [35], and Paraguay produces 85 thousand tons [36].

Within this social context and the potential savings associated with reuse of glass and yerba mate waste, this article reports the production of glass foams from glass bottles and yerba mate waste (as a pore forming agent). Different samples were prepared to obtain materials with controlled porosity for applications where thermal insulation and non-flammability are the main requirements. The results of this work serve as a basis for future studies aimed at applying these methods using Ilex paraguariensis residues to produce industrial products.

\section{MATERIALS AND METHODS}

In this study, green glass bottles (the soda-lime type) and yerba mate (Ilex paraguariensis) were used as alternative pore forming agents and raw materials. The glass bottles were washed and dried at $110^{\circ} \mathrm{C}$ for $2 \mathrm{~h}$. In a subsequent step, the dried glass bottles were then broken with a hammer and the resulting fragments were milled for $180 \mathrm{~min}$ in a fast mill (Servitech, CT-242) consisting of a porcelain jar containing alumina balls, and powders with particle sizes less than $44 \mu \mathrm{m}(325$ Mesh) were obtained. The average particle size distribution $\left(\mathrm{d}_{50}=2.45 \mu \mathrm{m}\right)$ of the resultant material was determined using a laser scattering particle size analyzer (CILAS 1180 Liquid).

Samples of dried yerba mate were milled so that a powder with a particle size below $90 \mu \mathrm{m}$ (170 Mesh) was obtained. The powder samples obtained were characterized by proximate chemical analysis according to procedures described in ASTM E1871-82 (2006) for moisture, ASTM E872-82 (2006) for volatile materials, ASTM E1755-01 (2007) for ash, and ASTM E1756-08 (2008) for total solids and fixed carbon.

The chemical characterization of the obtained glass powders and yerba mate was performed using X-ray fluorescence spectroscopy (XRF 1800, Shimadzu).

The samples of both wastes were dried at $110^{\circ} \mathrm{C}$ for $2 \mathrm{~h}$ and mixed (dry mixing in a ball mill for $5 \mathrm{~min}$ ) with different proportions of glass (70-90 wt \%) and yerba mate $(10-30 \mathrm{wt} \%)$ with the addition of $10 \%$ water. The prepared mixtures were uniaxial pressed $(40 \mathrm{MPa})$ at a later stage in a steel matrix by means of a hydraulic press. The obtained powder compacts (30 $\mathrm{mm}$ diameter) were dried at $110^{\circ} \mathrm{C}$ for $2 \mathrm{~h}$.

The thermal behavior during the firing of the raw materials was investigated using an optical dilatometer (ODHT, Misura) and also by thermogravimetric analyses, TG (TGA-50, Shimadzu) at $10^{\circ} \mathrm{C} / \mathrm{min}$ with a flow of synthetic air of $50 \mathrm{~cm}^{3} / \mathrm{min}$.

Based on the thermal analyses, green compacts were fired in a laboratory furnace (BTT 2374, Sanchis) at different temperatures $\left(850^{\circ} \mathrm{C}\right.$ and $\left.900^{\circ} \mathrm{C}\right)$ for $60 \mathrm{~min}$ with a heating rate of $10^{\circ} \mathrm{C} / \mathrm{min}$ followed by cooling to room temperature (approximately $25^{\circ} \mathrm{C}$ ).

The true densities $\left(\rho_{t}\right)$ of the powdered glass waste samples were determined using a helium pycnometer (AccuPyc 1340, Micromeritics, USA). The apparent densities $\left(\rho_{a}\right)$ of the fired samples were determined by relating their geometrical measurements obtained using a caliper (Mitutoyo, accuracy $\pm 0.01 \mathrm{~mm}$ ) and their masses (Shimadzu AX200 at 0.001 g). From measurements of geometrical and true densities, the porosities $(\varepsilon)$ of fired glass foams were calculated according to equation 1 .

$$
\varepsilon(\%)=\left[1-\left(\rho_{\mathrm{a}} / \rho_{\mathrm{t}}\right)\right] \times 100
$$

The microstructure of the pores of the obtained glass foams was observed and analyzed from images of fracture surfaces of samples obtained in an optical microscope (Olympus, 3Z61). Size and pore size distributions for the glass foams were determined by quantifications corresponding to the specified pore diameter ranges. This was based on the linear intercept method [37], where the ratio between the average length string $(\mathrm{t})$ and average sphere diameter (D) is given by Eq. (1) to better represent the measurement of a 3D unit (pore) by a 2D image.

$$
\mathrm{D}=1.623 \mathrm{t}
$$

In this case, five images of the fracture surfaces of each foam obtained were used, and 300 measurements of each image, on average, were made with aid of software (ImageJ $($ ) $)$.

To determine the mechanical strength of the glass foams, compressive strength tests were performed. Samples with nominal dimensions of $10 \times 10 \times 10 \mathrm{~mm}$ were tested in a universal test machine (Autograph AG$\mathrm{X}$, Shimadzu) with a crosshead speed of $1 \mathrm{~mm} / \mathrm{min}$ and a load cell of $2 \mathrm{KN}$ with a preload of $3 \mathrm{~kg}$. Ethylenevinyl acetate sheets were used on the samples for uniform charge distribution.

The thermal conductivity of the obtained materials was determined by a TCi Thermal Conductivity CTHERM TECHNOLOGIES on disk-shaped samples 30 $\mathrm{mm}$ in diameter.

\section{RESULTS AND DISCUSSION}

Table 1 shows the results of the proximate chemical analysis of the yerba mate samples. The proximate $80.5 \%$ volatile solid content indicates the presence of organic matter, which represents the lignocellulosic and carbon fractions present in the samples. This also expresses the weight of the components of the biomass, 
which are first thermally degraded and then oxidized during combustion [32,33]. After combustion, the remaining material corresponds to the ashes, which was approximately $8.5 \%$ for the yerba mate analyzed. The yerba mate and yerba mate ashes are rich in $\mathrm{CaO}, \mathrm{K}_{2} \mathrm{O}$, $\mathrm{SiO}_{2}, \mathrm{MnO}, \mathrm{P}_{2} \mathrm{O}_{5}$, and $\mathrm{MgO}$, which can be seen in Table 2. These components are in accordance with the findings of previous studies [38], and their presence will not affect the performance of the glass foams because they are of low concentration and do not make up part of the glass composition. Studies indicate low ash concentrations in the biomass range from $0.3-1 \%$, but in agricultural residues including rice husks, ash may represent $23 \%$, while this is less than $3 \%$ for sugar cane bagasse [29,39]. The fixed carbon content was approximately $7 \%$ and it is related to the mass of the material remaining after removal of the volatile components during firing, excluding ash and moisture. The moisture is approximately $5 \%$. The volatile solid content and the fixed carbon may be responsible for the vitreous foam formation.

Table 1. Proximate chemical and elemental analysis of yerba mate samples.

\begin{tabular}{|l|l|}
\hline Parameters & Content $(\mathrm{wt} \%)$ \\
\hline Moisture & $4.37 \pm 0.5$ \\
\hline Volatile solids & $80.60 \pm 0.4$ \\
\hline Fixed carbon & $6.96 \pm 0.4$ \\
\hline Ashes & $8.44 \pm 0.2$ \\
\hline
\end{tabular}

Table 2 shows the chemical composition of the glass bottle, yerba mate, and yerba mate ashes used in this study.

Table 2. Chemical analysis (X-ray fluorescence) of the glass waste, yerba mate, and yerba mate ashes.

\begin{tabular}{|c|c|c|c|}
\hline $\begin{array}{c}\text { Constituent } \\
\text { oxides }\end{array}$ & $\begin{array}{c}\text { Glass waste } \\
(\mathrm{wt} \%)\end{array}$ & $\begin{array}{c}\text { Yerba mate } \\
(\mathrm{wt} \%)\end{array}$ & $\begin{array}{c}\text { Yerba mate } \\
\text { ashes }(\mathrm{wt} \%)\end{array}$ \\
\hline $\mathrm{SiO}_{2}$ & 68.3 & 0.7 & 8.57 \\
\hline $\mathrm{Al}_{2} \mathrm{O}_{3}$ & 2.07 & 0.3 & 3.38 \\
\hline $\mathrm{Fe}_{2} \mathrm{O}_{3}$ & 0.41 & 0.5 & 1.30 \\
\hline $\mathrm{CaO}$ & 8.94 & 1.2 & 23.43 \\
\hline $\mathrm{K}_{2} \mathrm{O}$ & 0.44 & 1.7 & 25.55 \\
\hline $\mathrm{MgO}$ & 1.80 & 0.3 & 3.85 \\
\hline $\mathrm{Na}_{2} \mathrm{O}$ & 17.95 & & \\
\hline $\mathrm{P}_{2} \mathrm{O}_{5}$ & 0.01 & 0.3 & 4.23 \\
\hline $\mathrm{TiO}_{2}$ & 0.06 & & \\
\hline $\mathrm{MnO} \mathrm{P}_{2} \mathrm{O}_{5}$ & - & 0.2 & 5.33 \\
\hline $\mathrm{SO}_{3}$ & - & 0.3 & \\
\hline $\mathrm{CO}_{2}$ & - & 0.4 & 2.06 \\
\hline
\end{tabular}

It can be verified that the glass bottles samples are abundant in $\mathrm{SiO}_{2}, \mathrm{Na}_{2} \mathrm{O}$, and $\mathrm{CaO}$ in amounts typically found in soda-lime-silica glasses. The iron oxide $\left(\mathrm{Fe}_{2} \mathrm{O}_{3}\right)$ present in the sample is due to the green coloration of the glass bottles used. Because the applications envisaged in this work mainly relate to panels for thermal insulation used in buildings in general, no aesthetic requirements are necessary in terms of a specific color.

Figure 1 shows linear shrinkage curves for the recycled glass bottle samples, in addition to mass loss for yerba mate and yerba mate ashes (in detail) as a function of temperature. These data were obtained by optical dilatometry and thermogravimetric analysis. Glass densification (black line) starts at approximately $600^{\circ} \mathrm{C}$ and its softening begins at $700^{\circ} \mathrm{C}$ (Littleton softening point). From approximately $900^{\circ} \mathrm{C}$ (when the glass reaches its highest shrinkage and densification), the glass expansion occurs at temperatures up to $1000^{\circ} \mathrm{C}$ as a result of viscous liquid phase formation. At temperatures higher than $1000^{\circ} \mathrm{C}$, the viscosity of the glass gradually decreases. The yerba mate (blue line) showed three stages of thermal degradation. The first (from room temperature to about $150^{\circ} \mathrm{C}$ ) is related to moisture loss from the sample, corresponding to a weight loss of $6 \%$. These values are close to those found by proximate analysis, which was presented earlier. In the second stage, between $150-580^{\circ} \mathrm{C}$, the largest weight loss attributed to volatile materials and degradation of hemicellulose (the cellulose and lignin portion, which are constituents of the biomass) is registered. Mass loss for the yerba mate samples is $93 \%$. At this stage, it is also possible to identify the ignition temperature of the biomass combustion process. The thermal degradation of biomass products consists of moisture, volatiles, and ash. The volatiles are subdivided into gases, such as light hydrocarbons, carbon monoxide, carbon dioxide, and tar. Yields depend on the temperature and heating rate [39]. A third stage of mass loss can be observed above $580^{\circ} \mathrm{C}$. These are the ashes of the yerba mate. Ashes have a large amount of carbon that cause the formation of gases at temperatures between $600-1000^{\circ} \mathrm{C}$, which can be seen in detail in Figure 1.

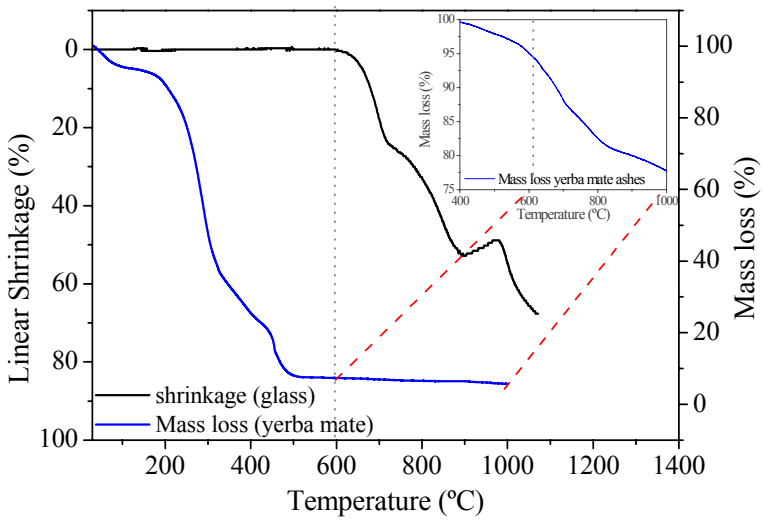

Figure 1. Linear shrinkage curve of the recycled glass bottles (black line) and mass loss for yerba mate (blue line) and yerba mate ashes (in detail) as a function of temperature.

The firing temperature for the production of glass foams is critical because it is directly related to the glass viscosity, and its expansion is caused by the gas release from the foaming agent decomposition $[3,40]$. In this case, two pore forming processes are effective. Initially, pores are formed in the vitreous matrix due to pyrolysis of the yerba mate, which acts as sacrificial material or template. These pores form, but do not cause matrix expansion. They only occupy the place previously occupied by the yerba mate. Thereafter, at temperatures above $600^{\circ} \mathrm{C}$, the carbon resulting from the pyrolysis of the yerba mate is responsible for the second process of pore formation. That is, there is an expansion of the vitreous matrix due to the release of gas (Figure 1- yerba 
mate ashes) at the temperature at which there is an adequate viscosity in the glass. The most convenient viscosity range for the expansion of the glass foam production with maximum porosity corresponds to temperatures between $800-1000^{\circ} \mathrm{C}$ for soda-lime glasses $[3,40]$.

Figure 2 shows the porosity of glass foams produced with different amounts of yerba mate fired at $850^{\circ} \mathrm{C}$ and $900^{\circ} \mathrm{C}$ for $60 \mathrm{~min}$.

As can be seen, the porosity of the produced glass foams ranges from $63.3-88.3 \%$. In general, with increasing amounts of yerba mate, there is increase in porosity. As the firing temperature increases from 800 $900^{\circ} \mathrm{C}$, the porosity remains practically constant for all studied compositions. This suggests that the main factor that influences porosity in this temperature range (850 $900^{\circ} \mathrm{C}$ ) is the amount of yerba mate. Studies show [13] that with higher firing temperatures, there is a decrease in the glass viscosity, which was not sufficient to maintain the cell structure because $950^{\circ} \mathrm{C}$, for example, is very close to its melting temperature.

Commercial glass foams have porosity values between $85-95 \%$ [11]. Therefore, some glass foam samples show porosity values higher than those found in commercial products processed under similar conditions, which was reported in previous studies [2-4, $6,10]$.

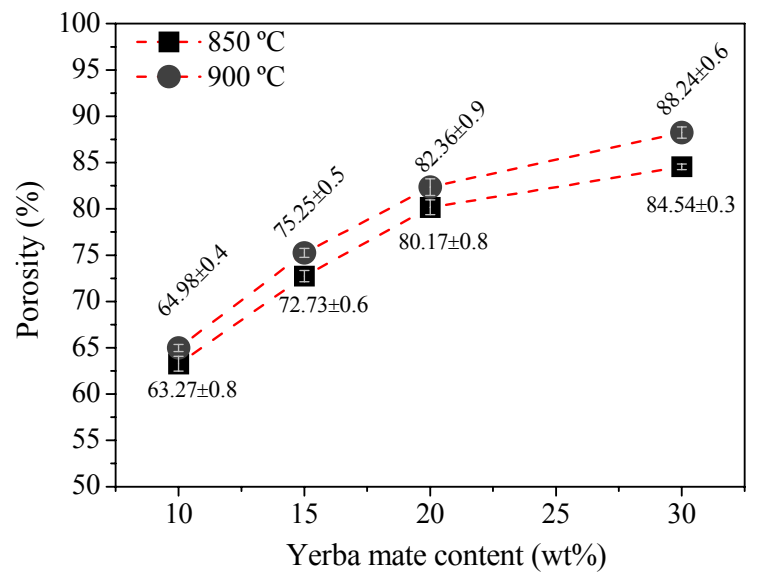

Figure 2. Porosity of glass foams produced with different contents of yerba mate $(10,15,20$ and $30 \%)$ fired at $850^{\circ} \mathrm{C}$ and $900^{\circ} \mathrm{C}$ for $60 \mathrm{~min}$.
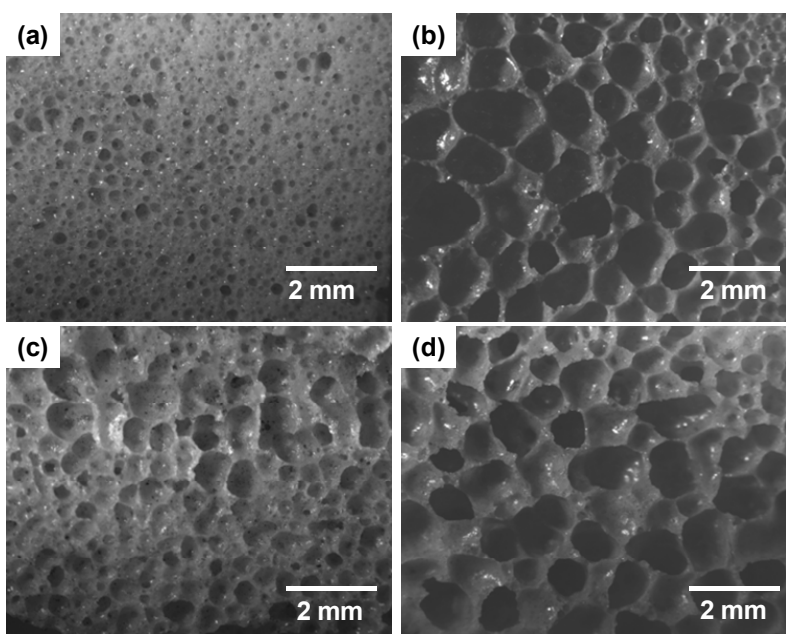

Figure 3. Optical micrograph of glass foams produced with different contents of yerba mate $(10 \%$ [a], $15 \%$ [b], $20 \%$ [c], and $30 \%$ [d]) fired at $850^{\circ} \mathrm{C}$ for $60 \mathrm{~min}$.
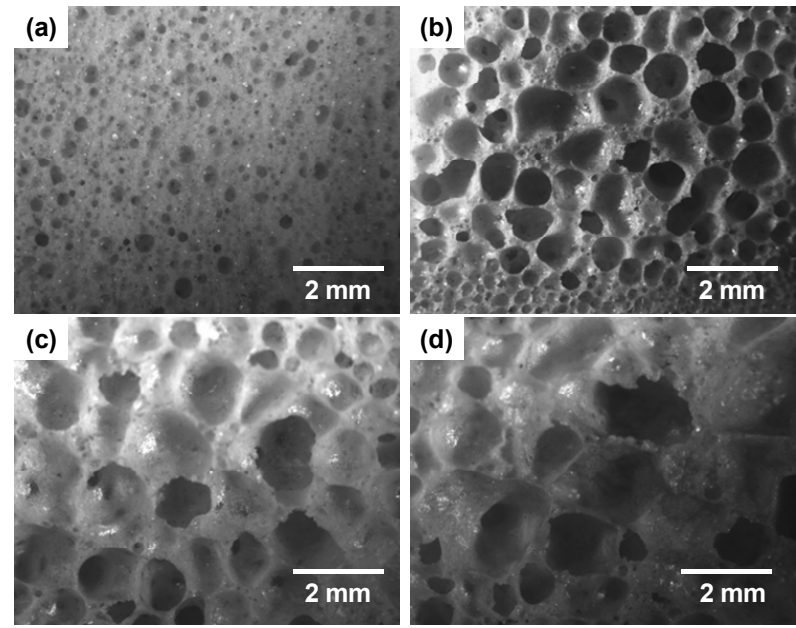

Figure 4. Optical micrograph of glass foams produced with different contents of yerba mate $(10 \%[a], 15 \%[b], 20 \%[c]$, and $30 \%$ [d]) fired at $900^{\circ} \mathrm{C}$ for $60 \mathrm{~min}$.

Figures 3 and 4 show optical micrographs of glass foams produced with different contents of yerba mate (10 [a], 15 [b], 20 [c], and 30\% [d]) fired for $60 \mathrm{~min}$ at $850^{\circ} \mathrm{C}$ (Figure 3 ) and $900^{\circ} \mathrm{C}$ (Figure 4), respectively.

From a visual inspection of the images, the samples are free of cracks (at least within the field of observation) with uniformly distributed pores having closed porosity, and very similar morphologies are observed for all glass foams obtained. These results are in agreement with the data shown in Figure 2. The porosity also increases with higher amounts of yerba mate.

Figure 5 shows histograms of the pore size distributions for the glass foams produced with different contents of yerba mate $(10,15,20$, and $30 \%)$ fired for $60 \mathrm{~min}$ at $850^{\circ} \mathrm{C}$ (a) and $900^{\circ} \mathrm{C} \mathrm{(b),} \mathrm{respectively.}$

According to the measurements in the histograms, it can be observed that the sample containing $10 \%$ yerba mate has the diameter for all pores below $1 \mathrm{~mm}$ for all firing temperatures. The small pores observed are mainly due to the low amount of porogenic agents. The sample containing $15 \%$ mate grass has a pore size distribution for which approximately $75 \%$ of the pores are smaller than $1 \mathrm{~mm}$ and $25 \%$ of the pores are $1-2$ $\mathrm{mm}$ when the firing temperature is $850^{\circ} \mathrm{C}$. The pore diameters increase significantly when the firing temperature increases. The pore diameter increases with increasing temperature for the $15 \%$ sample because there is a larger amount of carbon residue resulting from the pyrolysis process of the yerba mate. Subsequently, there is an expansion of the vitreous matrix as a result of the higher release of gas. This can be observed in the samples containing 20-30\% yerba mate. For the sample containing $30 \%$ yerba mate, pores ranging from 3-4 $\mathrm{mm}$ in diameter are also observed. From the analysis of Figures 3 and 4, there is a tendency for pore diameter to increase with increasing porosity. This is because increasing the amount of air inside the foam results in greater porosity. Such insertion is obtained by increasing the number of pores or their diameters.

Figure 6 shows the compressive strength results for the glass foams supplemented with $10,15,20$, and $30 \%$ yerba mate and fired at $850^{\circ} \mathrm{C}$ and $900^{\circ} \mathrm{C}$ for $60 \mathrm{~min}$. The mechanical strength is greatly influenced by the porosity. Specifically, the sample with the highest 
porosity (30\% yerba mate) has the lowest compressive strength (approximately $1.5 \mathrm{MPa}$ ) and the sample with one of the lowest porosity values $(10 \%$ yerba mate) has the highest compressive strength (approximately 15 $\mathrm{MPa}$ ). This result is in good agreement with the observed porosity results: it increases as the compressive strength decreases. There were no significant variations in compressive strength with increases in temperature. This can be explained by little variations in the porosity following the increase in temperature.
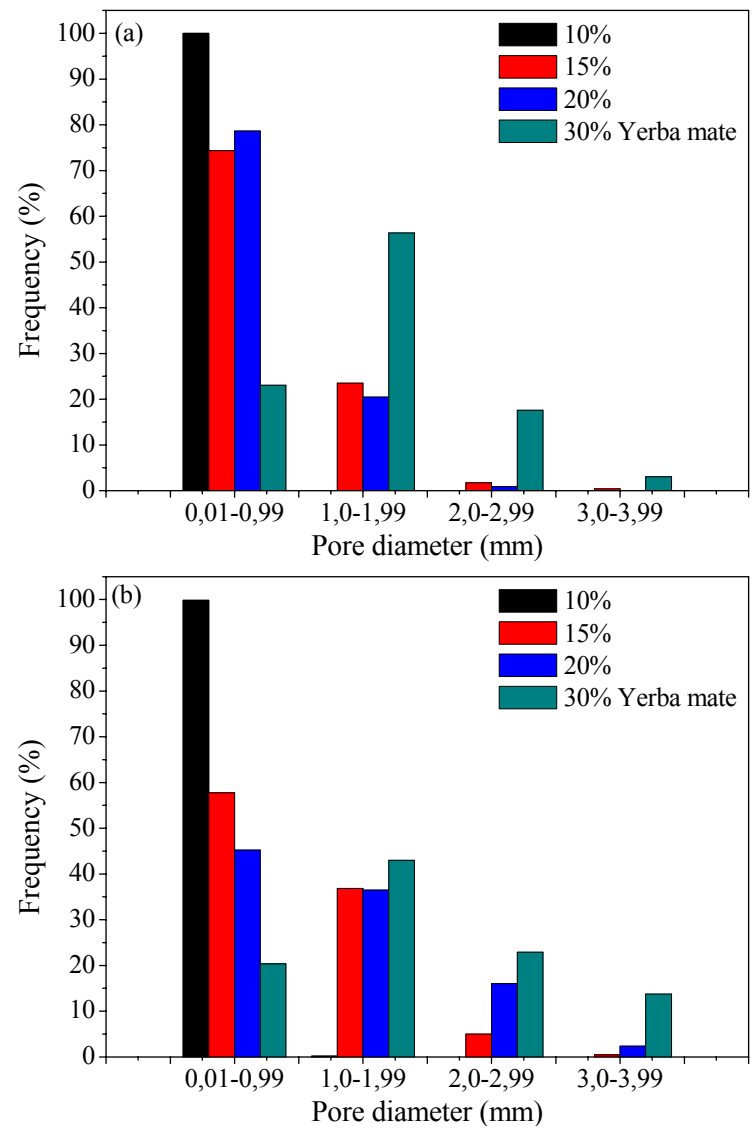

Figure 5. Pore diameters of glass foams produced with different contents of yerba mate $(10,15,20$, and $30 \%)$ fired at $850^{\circ} \mathrm{C}$ (a) and $900^{\circ} \mathrm{C}$ (b) for $60 \mathrm{~min}$.

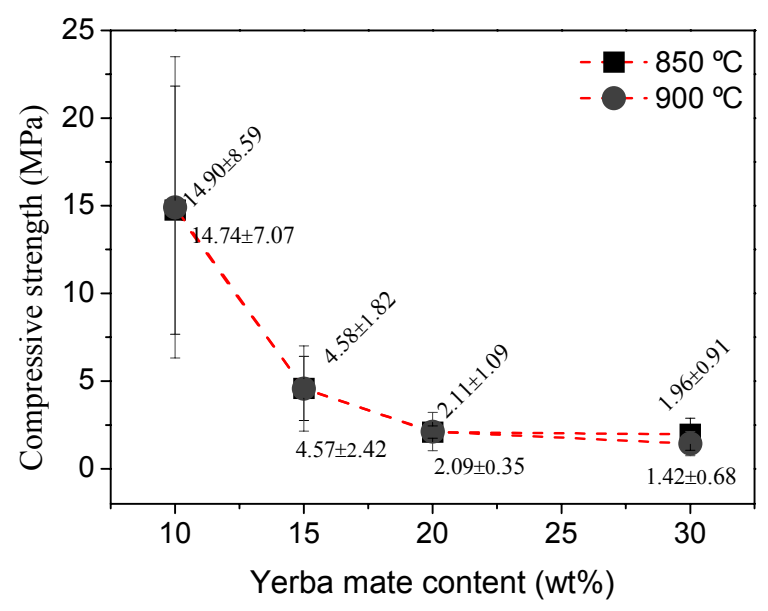

Figure 6. Compressive strength of glass foams produced with different contents of yerba mate $(10,15,20$, and $30 \%)$ fired at $850^{\circ} \mathrm{C}$ and $900^{\circ} \mathrm{C}$ for $60 \mathrm{~min}$.

Commercial glass foams typically have compressive strength values between $0.4-6 \mathrm{MPa}$ [11]. In this case, as shown in Figure 2, glass foams obtained with yerba mate contents between 15-30\% achieve the compressive strength range established. Thus, the glass foams obtained in this study satisfy the minimum requirements in terms of compressive strength.

Figure 7 shows the thermal conductivity results for the glass foams produced following the addition of 10 , 15,20 , and $30 \%$ yerba mate and firing at $850^{\circ} \mathrm{C}$ and $900^{\circ} \mathrm{C}$ for $60 \mathrm{~min}$. In general, the thermal conductivity decreases as the porosity increases (due to the yerba mate content). This is the result of the contribution of a higher porosity, which reduces thermal conductivity, especially in cases where the pores are closed and are not interconnected. In contrast, with the increase in temperature from $850^{\circ} \mathrm{C}$ to $900^{\circ} \mathrm{C}$, the thermal conductivity decreases. In this case, although the porosities are very similar, there is a greater contribution of the larger pore sizes in the glass foams obtained at $900^{\circ} \mathrm{C}$.

It is noteworthy that glass foams that contain 15, 20, and $30 \%$ yerba mate fired at $900^{\circ} \mathrm{C}$ have values of thermal conductivity within the range of values corresponding to the commercial glass foams (Figure 6 , blue area), which range from $0.04-0.08 \mathrm{~W} \cdot \mathrm{m}^{-1} \cdot \mathrm{K}^{-1}[11]$.

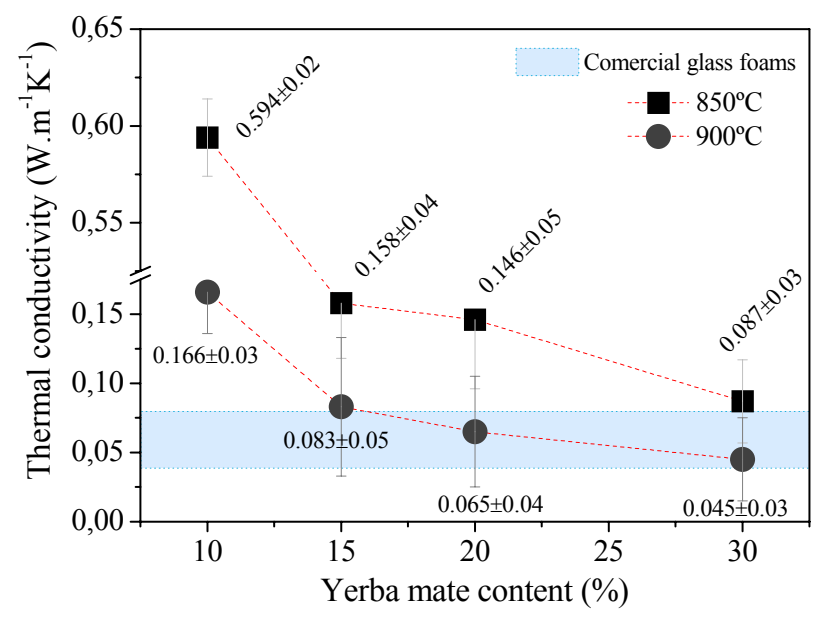

Figure 7. Thermal conductivity of glass foams produced with different contents of yerba mate $(10,15,20$, and $30 \%)$ fired at $850^{\circ} \mathrm{C}$ and $900^{\circ} \mathrm{C}$ for $60 \mathrm{~min}$.

\section{CONCLUSION}

Discarded glass bottles (90-70 wt \%) can be successfully converted into glass foams using Ilex paraguariensis (10-30 $\mathrm{wt} \%)$ as foaming agents, thus contributing to the sustainable life cycle of these materials, which are usually deposited in landfills, by recycling the glass and yerba mate wastes.

The glass foams produced after firing at $850^{\circ} \mathrm{C}$ and $900^{\circ} \mathrm{C}$ for $60 \mathrm{~min}$ have porosities between $66.3-88.3 \%$ and compressive strengths ranging from 15-1.5 $\mathrm{MPa}$. Their thermal conductivity ranges from $0.6-0.04 \mathrm{~W} \cdot \mathrm{m}^{-}$ ${ }^{1} \cdot \mathrm{K}^{-1}$.

This glass foam synthesis process is simple and does not require the use of toxic additives. The additive manufacturing can represent the right option for a gamma of industrial products [41,42]. Moreover, additional savings could be realized using an integrated 
approach for the full cost optimization of the process as a whole, instead of moving toward single steps of reduction for additive manufacturing and, separately, vacuum casting. Finally, the benefits provided by these new techniques toward a modern manufacturing also has to be considered in terms of eco-sustainability, evident when compared with conventional methods [43]. The properties we obtained for the end-products show that this method is adequate when the objective is to obtain materials with homogeneous microstructures, porosity, and good mechanical strength. The evaluated properties indicate that the glass foams generated can be used as heat insulation panels, which require an appropriate combination of thermal conductivity, porosity, and mechanical strength.

\section{ACKNOWLEDGMENTS}

The authors thank CAPES and CNPq for the financial support.

\section{REFERENCES}

[1] Ortega, F., Paiva, A., Rodrigues, J. and Pandolfelli, V.: Propriedades mecânicas de espumas cerâmicas produzidas via "gelcasting", Cerâmica, Vol. 49 No. 309, pp. 1-5, 2003.

[2] Arcaro, S., Maia, B.G.O., Souza, M.T., Cesconeto, F.R., Granados, L., and Oliveira, A.P.N.: Thermal Insulating Foams Produced From Glass Waste and Banana Leaves, Materials Research, Vol. 19, pp. 1064-1069, 2016.

[3] Souza, M.T., Maia, B.G.O., Teixeira, L.B., de Oliveira, K.G., Teixeira, A.H.B., and Novaes de Oliveira, A.P.: Glass foams produced from glass bottles and eggshell wastes, Process Safety and Environmental Protection, Vol. 111, pp. 60-64, 2017.

[4] Bernardo, E., Cedro, R., Florean, M. and Hreglich, S.: Reutilization and stabilization of wastes by the production of glass foams, Ceramics International, Vol. 33, No. 6, pp. 963-968, 2007.

[5] Dias, G.M., Arcaro, S., Cesconeto, F.R., Maia, B.G.O., Pereira, F.R. and Oliveira, A.P.: Production and Characterization of Glass Foams for Thermal Insulation, Chemical Engineering, Vol. 43, 2015.

[6] Zilli, M., Arcaro, S., Cesconeto, F.R., Maia, B.G., Pereira, F.R., and Oliveira, A.P.: Production and Characterization of Ceramic Foams from Industrial Solid Waste, Chemical Engineering, Vol. 43, 2015.

[7] Mugoni, C., Montorsi, M., Siligardi, C., Andreola, F., Lancellotti, I., Bernardo, E., and Barbieri, L.: Design of glass foams with low environmental impact, Ceramics International, Vol. 41, No. 3, pp. 3400-3408, 2015.

[8] Bernardo, E., Scarinci, G., Bertuzzi, P., Ercole, P., and Ramon, L.: Recycling of waste glasses into partially crystallized glass foams, Journal of Porous Materials, Vol. 17, No. 3, pp. 359-365, 2010.

[9] König, J., Petersen, R.R., and Yue, Y.: Fabrication of highly insulating foam glass made from CRT panel glass, Ceramics International, Vol. 41, No. 8, pp. 9793-9800, 2015.
[10] Pokorny, A., Vicenzi, J. and Bergmann, C.P.: Influence of heating rate on the microstructure of glass foams, Waste Management \& Research, Vol. 29, No. 2, pp. 172-179, 2010.

[11] Scheffler, M. and Colombo, P.: Cellular ceramics: structure, manufacturing, properties and applications, John Wiley \& Sons, Hoboken, 2006.

[12] König, J., Petersen, R.R., and Yue, Y.: Influence of the glass particle size on the foaming process and physical characteristics of foam glasses, Journal of Non-Crystalline Solids, Vol. 447, pp. 190-197, 2016.

[13] Teixeira, L., Fernandes, V., Maia, B., Arcaro, S., and de Oliveira, A.N.: Vitrocrystalline foams produced from glass and oyster shell wastes, Ceramics International, Vol. 43, No. 9, pp. 67306737, 2017.

[14] De Paola, S., Minak, G., Fragassa, C. and Pavlovic, A.: Green Composites: A Review of State of Art, in: Proc. 30th Danubia Adria Symposium on Advanced Mechanics, 25-28.09.2013, Primosten, pp. 77-78.

[15] Fragassa, C.: Effect of Natural Fibers and BioResins on Mechanical Properties in Hybrid and Non-Hybrid Composites, in: Proceedings of the 8th Conference on Times of Polymers \& Composites: From Aerospace to Nanotechnology, 1923.06.2016, Ischia.

[16] Rašuo, B.: Experimental Study of the Structural Damping of Composite Helicopter Blades with Different Cores, Plastics Rubber \& Composites, Vol. 39, No. 1, pp. 1-5, 2010.

[17] Dinulović, M., Rašuo, B., Krstić, B., Bojanić, A.: $3 \mathrm{D}$ random fiber composites as a repair material for damaged honeycomb cores, FME Transactions, Vol. 41 No 4, pp 325-332, 2013.

[18]Fragassa, C., Pavlovic, A. and Santulli, C.: Mechanical and impact characterisation of flax and basalt fibre bio-vinylester composites and their hybrids. Composites - Part B, 2017, doi: 10.1016/j.compositesb.2017.01.004

[19] Hyseni, A., De Paola, S., Minak, G. and Fragassa, C.: Mechanical Characterization of EcoComposites, in: Proc. 30th Danubia Adria Symposium on Advanced Mechanics, 25-28.09.2013, Primosten, pp. 175-176.

[20] Maglio, S., de Camargo F.V. and Rodrigues M.R.: Benefits and Risks in the Use of Composite Materials in Solar Vehicles, Key Engineering Materials, Vol. 754, pp. 51-54, 2017.

[21] Fragassa, C.: Marine Applications of Natural FibreReinforced Composites: A Manufacturing Case Study, in: Pellicer, E. et al. (Eds.): Advances in Application of Industrial Biomaterials, Springer International Publishing, Cham Switzerland, pp. 21-48, 2017.

[22] De Camargo, F.V., Fragassa, C., Pavlovic, A. and Martignani, M.: Analysis of the Suspension Design Evolution in Solar Cars, FME Transactions, Vol. 45, No. 3, pp. 394-404, 2017. 
[23] Minak. G., Fragassa, C. and de Carmago F.V.: A Brief Review on Determinant Aspects in Energy Efficient Solar Car Design and Manufacturing, in: Campana G. et al. (Eds.): Sustainable Design and Manufacturing 2017 - Smart Innovation, Systems and Technologies, Vol.68 Springer International Publishing, Cham Switzerland, pp. 847-856, 2017.

[24] Scarinci, G., Brusatin, G., Barbieri, L., Corradi, A., Lancellotti, I., Colombo, P., Hreglich, S., and Dall'Igna, R.: Vitrification of industrial and natural wastes with production of glass fibres, Journal of the European Ceramic Society, Vol. 20, No. 14, pp. 2485-2490, 2000.

[25] Gong, Y., Dongol, R., Yatongchai, C., Wren, A.W., Sundaram, S.K., and Mellott, N.P.: Recycling of waste amber glass and porcine bone into fast sintered and high strength glass foams, Journal of Cleaner Production, Vol. 112, pp. 4534-4539, 2016.

[26] Eriksson, O. et al.: Municipal solid waste management from a systems perspective, Journal of Cleaner Production, Vol. 13, No. 3, pp. 241-252, 2005.

[27] Gibson, L.J. and Ashby, M.F.: Cellular solids: structure and properties, Cambridge university press, Cambridge, 1999.

[28] Studart, A.R., Gonzenbach, U.T., Tervoort, E., and Gauckler, L.J.: Processing routes to macroporous ceramics: a review, Journal of the American Ceramic Society, Vol. 89, No. 6, pp. 1771-1789, 2006.

[29] Sellin, N., de Oliveiraa, B.G., Marangonia, C., Souzaa, O., de Oliveirab, A.P.N., and de Oliveira, T.M.N.: Use of banana culture waste to produce briquettes, Chemical Engineering, Vol. 32, 2013.

[30] Junior, E.L.C. and Morand, C.: Interest of mate (Ilex paraguariensis A. St.-Hil.) as a new natural functional food to preserve human cardiovascular health-A review, Journal of Functional Foods, Vol. 21, pp. 440-454, 2016.

[31] Caron, B.O., Santos, D.R.d., Schmidt, D., Basso, C.J., Behling, A., Eloy, E., and Bamberg, R.: Biomass and accumulation of nutrients in Ilex paraguariensis A. St. Hil, Ciência Florestal, Vol. 24, No. 2, pp. 267-276, 2014.

[32] de Oliveira, Y.M.M. and Rotta, E: Área de distribuição natural de erva-mate (Ilex paraguariensis St. Hil.), in: Embrapa FlorestasArtigo em anais de congresso. 1983: seminário sobre atualidades e perspectivas florestais, 1985, Curitiba, pp. 17-36.

[33] Wendling, I., Propagação vegetativa de erva-mate (Ilex paraguariensis Saint Hilaire): Estado da arte e tendências futuras. 2004.

[34] IBGE. Instituto Brasileiro de Geografia e Estatí-stica. 2013 03/08/2017; Available from: www.ibge.gov.br.

[35] INYM. Instituto Nacional do Mate. 2013 [cited 2017 03/08/2017]; Available from: www.inym.org.ar.

[36]MAG. Ministerio de Agricultura y Ganadería. 2013; Available from: www.mag.gov.py.

[37]ASTM, Standard Test Method for Cold Crushing Strength and Modulus of Rupture of Refractories, in C 133-97. 1997: Annual Book of ASTM Standards. pp. 6.

[38] Gonzalez de Mejia, E., Song, Y.S., Ramirez-Mares, M.V. and Kobayashi, H.: Effect of yerba mate (Ilex paraguariensis) tea on topoisomerase inhibition and oral carcinoma cell proliferation, Journal of agricultural and food chemistry, Vol. 53, No. 6, pp. 1966-1973, 2005.

[39] Demirbas, A.: Combustion characteristics of different biomass fuels, Progress in energy and combustion science, Vol. 30, No. 2, pp. 219-230, 2004.

[40] Petersen, R.R., König, J. and Yue, Y.: The viscosity window of the silicate glass foam production, Journal of Non-Crystalline Solids, Vol. 456, p. 49$54,2017$.

[41] Grujovic, N., Pavlovic, A., Sljivic, M. and Zivic, F.: Cost optimization of additive manufacturing in wood industry, FME Transactions, Vol. 44, No 4, 2016.

[42] Sljivic, M., Pavlovic, A., Stanojevic, M. and Fragassa, C.: Combining Additive Manufacturing and Vacuum Casting for an Efficient Manufacturing of Safety Glasses, FME Transactions, Vol. 44, No 4, 2016.

[43] Bulian, F. and Fragassa C.: VOC emissions from wood products and furniture: a survey about legislation, standards and data referred to different materials, FME Transactions, Vol. 44, No 4, 2016.

[44] Maglio, S., de Camargo F.V. and Rodrigues M.R.: Benefits and Risks in the Use of Composite Materials in Solar Vehicles, Key Engineering Materials, Vol. 754, pp. 51-54, 2017.

[45] Fragassa, C.: Marine Applications of Natural FibreReinforced Composites: A Manufacturing Case Study, in: Pellicer, E. et al. (Eds.): Advances in Application of Industrial Biomaterials, Springer International Publishing, Cham Switzerland, pp. 21-48, 2017.

[46] de Camargo, F.V., Fragassa, C., Pavlovic, A. and Martignani, M.: Analysis of the Suspension Design Evolution in Solar Cars, FME Transactions, Vol. 45, No. 3, pp. 394-404, 2017.

[47] Minak. G., Fragassa, C. and de Carmago F.V.: A Brief Review on Determinant Aspects in Energy Efficient Solar Car Design and Manufacturing, in: Campana G. et al. (Eds.): Sustainable Design and Manufacturing 2017 - Smart Innovation, Systems and Technologies, Vol.68 Springer International Publishing, Cham Switzerland, pp. 847-856, 2017.

[48]Beaumont P.W.R., Soutis C. and Hodzic A. (Editors): Structural integrity and durability of advanced composites: Innovative modelling methods and intelligent design, Woodhead Publishing - Elsevier, Cambridge, UK, 2015.

[49] Garinis D., Dinulovic M, Rašuo B.: Dynamic Analysis of Modified Composite Helicopter Blade, FME Transactions, Vol. 40 No 2, 2012, pp 63-68.

[50] Rasuo, B.: Experimental Techniques for Evaluation of Fatigue Characteristics of Laminated Const-ructions 
from Composite Materials: Full-Scale Testing of the Helicopter Rotor Blades, Journal of Testing and Evaluation (JTE), Volume 39, Issue 2 (March 2011), ASTM International, USA, pp. 237-242.

[51]Rasuo, B.: An Experimental Methodology for Evaluating Survivability of an Aeronautical Constructions from Composite Materials: An Overview, International Journal of Crashworthiness, Volume 12, Issue 1, Taylor \& Francis, London, 2007, pp. 9-15.

[52] Advani, S.G.: Processing and Properties of Nanocomposites, World Scientific Publishing, Singapore, 2007.

[53] Chung, D.D.L.: Composite Materials: Science and Applications, Springer, London, 2010.

[54] Gao, H., Ji, B., Jäger, I.L., Arzt E. and Fratzl P.: Materials become insensitive to flaws at nanoscale: lessons from nature, Proceedings of the national Academy of Sciences, Vol. 100, pp. 5597-5600, 2003.

[55] Boria, S., Pavlovic, A., Fragassa, C. and Santulli, C.: Modeling of Falling Weight Impact Behavior of Hybrid Basalt/Flax Vinylester Composites, Procedia Engineering, Vol. 167, pp. 223-230, 2016.

[56] Saghafi, H., Brugo, T., Zucchelli, A., Fragassa, C. and Minak, G.: Comparison the effect of pre-stress and curvature of composite laminate under impact loading, FME Transactions, Vol. 44, No. 4, pp. 353-357, 2016.

[57] De Camargo, F.V. and Pavlovic, A.: Fracture Evaluation of the Falling Weight Impact Behaviour of a Basalt/Vinylester Composite Plate through a Multiphase Finite Element Model, Key Engineering Materials, Vol. 754, pp. 59-62, 2017.

[58] Krishnaraj, V., Zitoune, R. and Davim, J.P.: Drilling of polymer-matrix composites, Springer, 2013.

[59] El-Sonbaty, I., Khashaba, U.A. and Machaly T.: Factors affecting the machinability of GFR/epoxy composites, Composite Structures, Vol. 63, pp. 329-338, 2004.

[60] Mohammadi, R., Ahmadi Najafabadi, M., Saeedifar, M., Yousefi, J. and Minak, G.: Correlation of acoustic emission with finite element predicted damages in open-hole tensile laminated composites, Composites Part B: Engineering, Vol. 108, pp. 427-435, 2017.

[61] Fotouhi, M., Saeedifar, M., Sadeghi, S., Ahmadi Najafabadi, M. and Minak, G.: Investigation of the damage mechanisms for mode I delamination growth in foam core sandwich composites using acoustic emission, Structural Health Monitoring, Vol. 14, pp. 265-280, 2015.

[62] Fotouhi, M., Sadeghi, S., Jalalvand, M., and Ahmadi Najafabadi, M.: Analysis of the damage mechanisms in mixed-mode delamination of laminated composites using acoustic emission data clustering, Journal of Thermoplastic Composite Materials, Vol. 30, pp. 318-340, 2017.
[63] Yousefi, J., Ahmadi Najafabadi, M., Shahri, M.N., Oskouei, A.R. and Moghadas, F.J.: Damage Categorization of Glass/Epoxy Composite Material Under Mode II Delamination Using Acoustic Emission Data, A Clustering Approach to Elucidate Wavelet Transformation Analysis, Arabian Journal for Science and Engineering, Vol. 39, pp. 13251335, 2014.

[64] Zarif Karimi, N., Heidary, H. and Minak, G.: Critical thrust and feed prediction models in drilling of composite laminates, Composite Structures, Vol. 148, pp. 19-26, 2016.

[65] Abdul Nasir, A.A., Azmi, A.I. and Khalil, A.N.M.: Measurement and optimisation of residual tensile strength and delamination damage of drilled flax fibre reinforced composites, Measurement, Vol. 75, pp. 298-307, 2015.

[66] Sridharan, S.: Delamination behaviour of composites, Elsevier, 2008.

[67]Liu, D., Tang, Y. and Cong, W.L.: A review of mechanical drilling for composite laminates, Composite Structures, Vol. 94, pp. 1265-1279, 2012.

[68] Grilo, T.J., Paulo, R.M.F., Silva, C.R.M. and Davim, J.P.: Experimental delamination analyses of CFRPs using different drill geometries, Composites Part B: Engineering, Vol. 45, pp. 1344-1350, 2013.

[69] Capello, E.: Workpiece damping and its effect on delamination damage in drilling thin composite laminates, Journal of Materials Processing Technology, Vol. 148, pp. 186-195, 2004.

[70] Capello. E. and Tagliaferri, V.: Drilling damage of GFRP and residual mechanical behavior-part I: drilling damage generation, Journal of composites technology \& research, Vol. 23, pp. 122-130, 2001.

[71] Davim, J.P.: Study of drilling metal-matrix composites based on the Taguchi techniques, Journal of Materials Processing Technology, Vol. 132, pp. 250-254, 2003.

[72]Zarif Karimi, N., Heidary, H., Fotouhi, M. and Minak, G.: Experimental analysis of GFRP laminates subjected to compression after drilling, Composite Structures, Vol. 169, pp. 144-152, 2017.

[73] Davim, J.P. et al.: Experimental study of drilling glass fiber reinforced plastics (GFRP) manufactured by hand lay-up, Composites Science and Technology, Vol. 64, pp. 289-297, 2004.

[74] Tsao, C.C. and Hocheng, H.: Computerized tomography and C-Scan for measuring delamination in the drilling of composite materials using various drills, International Journal of Machine Tools and Manufacture, Vol. 45, pp. 1282-1287, 2005.

[75]Zarif Karimi, N. et al.: Effect of the drilling process on the compression behavior of glass/epoxy laminates, Composite Structures, Vol. 98, pp. 5968, 2013.

[76] Arul, S., Vijayaraghavan, L., Malhotra, S.K. and Krishnamurthy, R.: The effect of vibratory drilling 
on hole quality in polymeric composites, International Journal of Machine Tools and Manufacture, Vol. 46, pp. 252-259, 2006.

[77] Heidary, H., Zarif Karimi, N., Ahmadi Najafabadi, M., Rahimi and A., Zucchelli, A.: Clustering of acoustic emission signals collected during drilling process of composite materials using unsupervised classifiers, Journal of Composite Materials, Vol. 49, pp. 559-571, 2014.

[78] Gaitonde, V.N., Karnik, S.R., Rubio, J.C., Correia, A.E., Abrão, A.M. and Davim, J.P.: Analysis of parametric influence on delamination in high-speed drilling of carbon fiber reinforced plastic composites, Journal of Materials Processing Technology, Vol. 203, pp. 431-438, 2008.

[79] Zarif Karimi, N., Minak, G. and Kianfar, P.: Analysis of damage mechanisms in drilling of composite materials by acoustic emission, Composite Structures, Vol. 131, pp. 107-114, 2015.

[80] Gaitonde, V.N., Karnik, S.R. and Davim, P.J.: Taguchi multiple-performance characteristics optimization in drilling of medium density fibreboard (MDF) to minimize delamination using utility concept, Journal of Materials Processing Technology, Vol. 196, pp. 73-78, 2008.

[81] Davim, J.P. and Reis, P.: Drilling carbon fiber reinforced plastics manufactured by autoclave experimental and statistical study, Materials \& design, Vol. 24, pp. 315-324, 2003.

[82] Sardiñas, R.Q., Reis, P. and Davim, J.P.: Multiobjective optimization of cutting parameters for drilling laminate composite materials by using genetic algorithms, Composites Science and Technology, Vol. 66, pp. 3083-3088, 2006.

[83] Kilickap, E.: Optimization of cutting parameters on delamination based on Taguchi method during drilling of GFRP composite, Expert Systems with Applications, Vol. 37, pp. 6116-6122, 2010.

[84] Khashaba, U.A.: Delamination in drilling GFRthermoset composites, Composite Structures, Vol. 63, pp. 313-327, 2004.

[85] Karnik, S.R., Gaitonde, V.N., Rubio, J.C., Correia, A.E., Abrão, A.M., Davim, J.P.: Delamination analysis in high speed drilling of carbon fiber reinforced plastics (CFRP) using artificial neural network model, Materials \& Design, Vol. 29, pp. 1768-1776, 2008.

[86] Campos Rubio, J., Abrao, A.M., Faria, P.E., Correia, A.E. and Davim, J.P.: Effects of high speed in the drilling of glass fibre reinforced plastic: Evaluation of the delamination factor, International Journal of Machine Tools and Manufacture, Vol. 48, pp. 715-720, 2008.

[87] Tsao, C.C. and Hocheng, H.: Taguchi analysis of delamination associated with various drill bits in drilling of composite material, International Journal of Machine Tools and Manufacture, Vol. 44, pp. 1085-1090, 2004.

[88] Hocheng, H. and Tsao, C.C.: Effects of special drill bits on drilling-induced delamination of composite materials, International Journal of Machine Tools and Manufacture, Vol. 46, pp. 1403-1416, 2006.

[89] Ponnuvel, S. and Moorthy, T.V.: Investigation on the Influence of Multi Walled Carbon Nanotubes on Delamination in Drilling Epoxy/Glass Fabric Polymeric Nanocomposite, Procedia Engineering, Vol. 51, pp. 735-744, 2013.

[90] Ponnuvel, S. and Moorthy, T.V.: Multi-criteria optimisation in drilling of epoxy/ glass fabric hybrid nanocomposite using grey relational analysis. In Applied Mechanics and Materials, Vol. 446-447, pp. 172-175,2014.

[91] Montgomery, D.C.: Design and analysis of experiments, John Wiley and Sons Inc., Hoboken, 2012.

[92]Roy, R.K.: A Primer on the Taguchi Method, Second Edition, Society of Manufacturing Engineers, 2010.

[93] Zarif Karimi, N., Heidary, H. and Ahmadi, M.: Residual tensile strength monitoring of drilled composite materials by acoustic emission, Materials \& Design, Vol. 40, pp. 229-236, 2012.

[94] Abrão, A.M., Faria, P.E., Rubio, J.C.C., Reis, P. and Davim, J.P.: Drilling of fiber reinforced plastics: A review, Journal of Materials Processing Technology, Vol. 186, pp. 1-7, 2007.

[95]Chen, W.C.: Some experimental investigations in the drilling of carbon fiber-reinforced plastic (CFRP) composite laminates, International Journal of Machine Tools and Manufacture, Vol. 37, pp. 1097-1108, 1997.

[96] Davim, J.P., Rubio, J.C. and Abrao, A.M.: A novel approach based on digital image analysis to evaluate the delamination factor after drilling composite laminates, Composites Science and Technology, Vol. 67, pp. 1939-1945, 2007.

[97] Sheikh-Ahmad, J.Y.: Machining of polymer composites, Springer, Berlin, 2009.

\section{СТАКЛЕНЕ ПЕНЕ ПРОИЗВЕДЕНЕ ИЗ СТАКЛА И ОТПАДА БИЉКЕ МАТЕ (Ilex paraguarinensis)}

Л. Л. да Силва, Л. Ц. Н. Рибеиро, Г. Сантакруз, С. Аркаро, А. К. Алвес, Ц. П. Бергман

У овом истраживању припремљени су препарати који садрже зелене стаклене бочице и осушену и дробљену биљку мате (Ilex paraguarinensis) различитих масених фракција (10-30\%) за добијање стаклене пене за потребе топлотне изолације. Ове композиције су једноосно притиснуте (за $40 \mathrm{MPa}$ ), а компактни прахови печени су на $850^{\circ} \mathrm{C}$ и $900^{\circ} \mathrm{C}$ у трајању од 60 минута како би се испитао утицај биљке мате и температуре на формирање пора и термичких и механичких особина обрађених стаклених пена. Резултати указују да стаклене пене показују порозности у распону од 65,3-88,3\%, јачину притиска у распону од 15 - 
1,5 МРа и топлотну проводљивост у распону од 0,6$0,04 \mathrm{Wm}^{-1} \mathrm{~K}^{-1}$. Кумулативно, ове стаклене пене су кандидати за термичке изолаторе који имају погодне особине за различите индустријске примене. 